\title{
A transição nutricional e a epidemiologia da obesidade na América Latina
}

São escassos os estudos de base populacional produzidos até hoje com a população brasileira cujo enfoque principal sejam os problemas nutricionais. Como exemplos, devemos destacar o Estudo Nacional sobre Despesas Familiares (ENDEF), realizado entre $1974 \mathrm{e}$ 1975; a Pesquisa Nacional sobre Saúde e Nutrição (PNSN), de 1989; e mais recentemente, a Pesqui sa sobre Padrões de Vida (PPV), desenvolvida em 1997. A adequada análise dos resultados desses estudos foi de grande importância por várias razões; primeiro, porque permitiu avaliar a magnitude dos agravos nutricionais mais relevantes, bem como mapear alguns dos seus principais determinantes; segundo, porque depois de realizados em intervalos sistemáticos, permitiu estudar a tendência dos problemas nutricionais.

É importante que se diga, que esses estudos, quando bem explorados, se constituem na base de boa parte da discussão sobre transição nutricional feita no Brasil até os dias de hoje. Entende-se por transição nutricional, o fenômeno no qual ocorre uma inversão nos padrões de distribuição dos problemas nutricionais de uma dada população no tempo, ou seja, uma mudança na magnitude e no risco atribuível de agravos associados ao padrão de determinação de doenças atribuídas ao atraso e à modernidade, sendo em geral, uma passagem da desnutrição para a obesidade.

É incontestável que o Brasil e diversos países da América Latina estão experimentando nos últimos vinte anos uma rápida transição demográfica, epidemiológica e nutricional. As características e os estágios de desenvolvimento da transição diferem para os vários países da América Latina. No entanto, um ponto chama a atenção, o marcante aumento na prevalência de obesidade nos diversos subgrupos populacionais para quase todos os países latino-americanos. Dentro desse contexto, a obesidade se consolidou como agravo nutricional associado a uma alta incidência de doenças cardiovasculares, câncer e diabetes, influenciando desta maneira, no perfil de morbi-mortalidade das populações.

Nos últimos anos, pôde se perceber uma intensa migração no foco das pesquisas realizadas por diversos grupos de pesquisadores da América Latina, o que demonstra a crescente importância da obesidade como tema de investigações científicas. Apesar de ter sido acumulado até o momento um relativo conhecimento sobre os padrões de determinação e de distribuição da obesidade, dentro do contexto da transição nutricional, muito ainda se faz necessário, sobretudo, no campo da prevenção e intervenção populacional.

A proposta desse volume temático é tentar colaborar no melhor entendimento da dinâmica do fenômeno de transição nutricional, e sobretudo, do papel que a obesidade exerce hoje, no complexo perfil epidemiológico das populações latino-americanas. São apresentadas quatro revisões de literatura e catorze artigos originais. As análises vão desde grupos populacionais pontuais de um único país, até análises mais globais, tendo como cenário mais amplo, os países da América Latina. O volume traz inúmeras questões interessantes que podem ser levantadas para debates, além de suscitar novas idéias e pesquisas, ao enfocar as diversas facetas da transição nutricional e da obesidade em distintos grupos populacionais de países tão diferentes como Peru, Chile, Argentina, Uruguai e Brasil.

Em síntese, esses estudos confirmam a crescente magnitude da obesidade em crianças, adolescentes, adultos e mulheres em idade reprodutiva. Apontam como determinantes, o estilo de vida sedentário e o consumo de dietas inadequadas, e mais que tudo, clamam por uma maior diversi dade de intervenções e apoio governamental com a implementação de ações claras de prevenção e combate à obesidade. A obesidade hoje não se resume mais a um problema presente apenas nos países ditos desenvolvidos, mas sim, afeta cada vez maiores parcelas dos estratos populacionais menos favorecidos. $O$ alerta está dado. Agora só precisamos agir.

Gilberto Kac

Instituto de Nutrição, Universidade Federal do Rio de Janeiro, Rio de Janeiro, Brasil.
Gustavo Velásquez-Meléndez

Escola de Enfermagem, Universidade Federal de Minas Gerais, Belo Horizonte, Brasil. 


\section{The nutritional transition and the epidemiology of obesity in Latin America}

There have been few population-based studies in Brazil to date whose principal focus has been nutritional problems. Important examples include the National Household Budget Survey (ENDEF), conducted in 1974 and 1975; the National Survey on Health and Nutrition (PNSN) in 1989; and more recently the Survey on Living Standards (PPV) in 1997. A correct analysis of the results of these surveys proved extremely important for several reasons: first, it allowed for an evaluation of the magnitude of the most relevant nutritional problems in the country; second, having been performed at systematic intervals, it allowed for a study of the trend in nutritional problems.

It is important to highlight that insofar as such studies have been properly explored, they have provided the basis for a major share of the discussion on the nutritional transition in Brazil to date. Nutritional transition is defined here as the phenomenon by which there is an inversion in the distribution patterns of nutritional problems among a given population over time, that is, a change in the magnitude and attributable risk of health problems associated with the pattern of determination of diseases attributed to backwardness and modernity, generally a shift from malnutrition to obesity.

It is undeniable that in the last twenty years Brazil and various other Latin American countries have undergone a rapid demographic, epidemiological, and nutritional transition. The characteristics and stages of development in the transition differ among the various Latin American countries. However, one point stands out, namely the marked increase in the prevalence of obesity in the various population sub-groups in nearly all Latin American countries. Within this context, obesity has taken hold as a nutritional problem associated with a high incidence of cardiovascular diseases, cancer, and diabetes, thereby influencing the morbidity and mortality profile of populations.

In recent years one observes an intense shift in the focus of studies performed by various research groups in Latin America, thereby demonstrating the growing importance of obesity as a theme for scientific investigation. Despite the accumulation of a certain amount of knowledge concerning the determination and distribution patterns of obesity within the context of the nutritional transition, much remains to be done, especially in the field of prevention and population intervention.

The proposal of this thematic issue is to collaborate towards a better understanding of the dynamics of the nutritional transition and above all the role that obesity now plays in the complex epidemiological profile of Latin American populations. The thematic issue presents four literature reviews and fourteen original articles. The analyses range from specific population groups in a single country to more overall analyses, with the Latin American countries as the broader scenario. The journal raises numerous interesting questions for debates - in addition to providing stimulus for ideas and research - by focusing on various facets of the nutritional transition and obesity in distinct population groups from such diverse countries as Peru, Chile, Argentina, Uruguay, and Brazil.

In short, these studies confirm the growing magnitude of the obesity problem in children, adolescents, adults, and childbearing-age women. As determinants, they identify sedentary lifestyle and consumption of inadequate diets. Above all, they issue a call for a greater diversity of interventions and government support with the implementation of clear measures for preventing and combating obesity. Obesity today is no longer a problem only for the so-called developed countries; rather, it increasingly affects growing portions of the most underprivileged population strata. The warning has been issued. We must act now.

Gilberto Kac

Instituto de Nutrição, Universidade Federal do Rio de Janeiro, Rio de Janeiro, Brasil.
Gustavo Velásquez-Meléndez

Escola de Enfermagem, Universidade Federal de Minas Gerais, Belo Horizonte, Brasil. 